Vol. 12, No. 42000

VOL. 12, NO. 42000 
EDITOR

Donald T. Critchlow

\title{
ASSOCIATE EDITOR/BOOK REVIEW EDITOR
}

David B. Robertson

University of Missouri, St. Louis

\author{
MANAGING EDITOR \\ William Glankler \\ COPYEDITOR \\ Cherene Holland \\ EDITORIAL ASSOCIATE \\ Patricia E. Powers
}

EDITORIAL BOARD

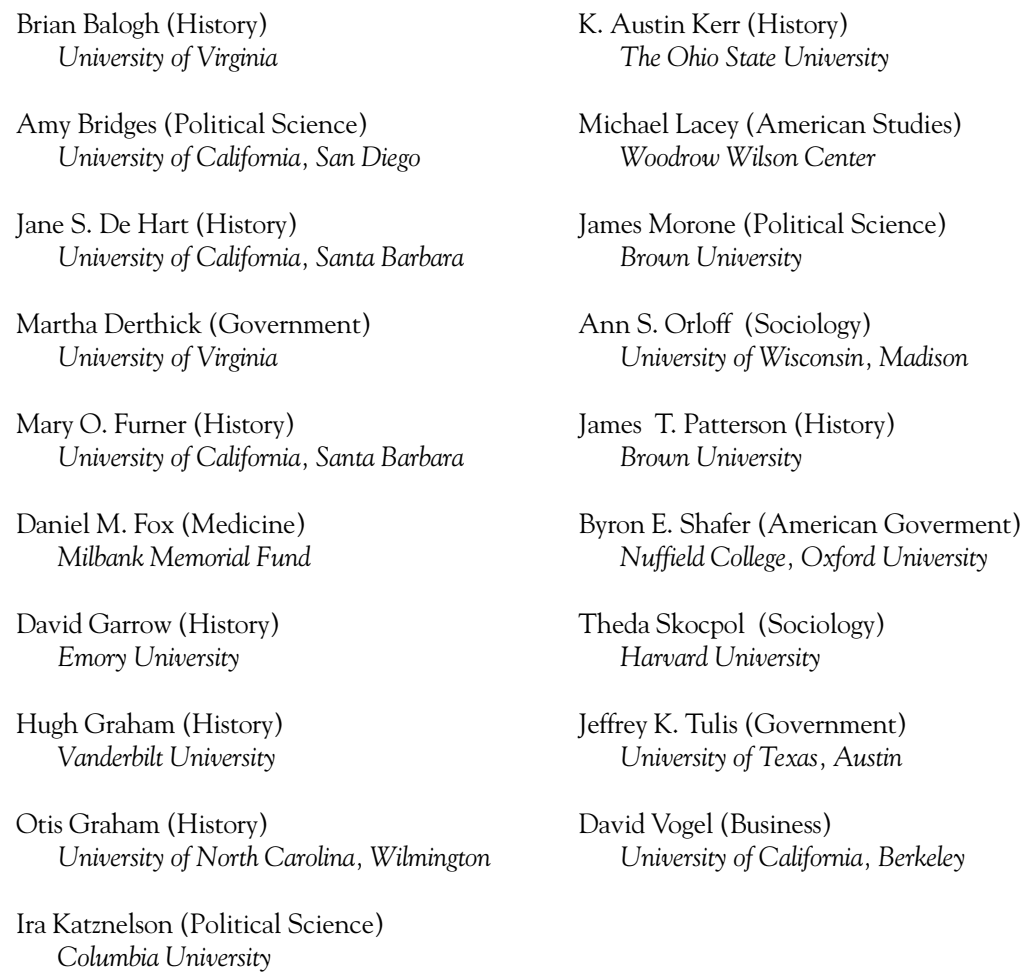




\section{Forthcoming Articles}

Next Issue:

Hugh Heclo, ed., Religion, Politics, and Policy

Stanley Carlson-Theis (Center for Public Justice), "Charitable Choice: Bringing Religion Back into American Welfare"

John A. Coleman, S.J. (Loyola Marymount University), "American Catholicism, Catholic Charities U.S.A., and Welfare Reform"

Charles L. Glenn (Boston University), "Public Education Changes Partners"

D. G. Hart (Westminster Theological Seminary), "Mainstream Protestantism, 'Conservative' Religion, and Civil Society”

Wilfred M. McClay (University of Tennessee at Chattanooga), "Two Concepts of Secularism"

A. James Reichley (Georgetown University), "Faith in Politics"

Special Issues

Hugh Heclo (George Mason University), "Religion, Politics, and Policy" (Winter 2001)

Paula Baker (University of Pittsburgh), "Money and Politics" (Winter 2002) 


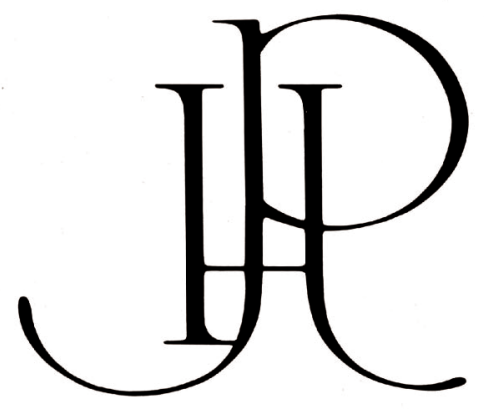

\section{Contents Vol. 12, No. 42000}

\section{Articles}

KAREN E. SCHNIETZ

The Institutional Foundation of U.S. Trade Policy:

Revisiting Explanations for the 1934 Reciprocal

Trade Agreements Act

CARL F. AMERINGER

Organized Medicine on Trial: The Federal Trade

Commission vs. the American Medical Association

JOHN AUBREY DOUGLASS

Earl Warren's "New Deal": Economic Transition,

Postwar Planning, and Higher Education in California

\section{Forum}

BYRON E. SHAFER

Who, What, When, Where, and How

Response to Byron Shafer 


\section{Book Reviews}

STACY A. CORDERY/Eleanor Roosevelt:

Compassion Set the Agenda

Blanche Wiesen Cook, Eleanor Roosevelt, Volumes I and II

MARY O. FURNER/Politics and Structure:

Open and Shut Cases

Gerald Berk, Alternative Tracks: The Constitution

of the American Industrial Order, 1865-1917

Colleen A. Dunlavy, Politics and Industrialization:

Early Railroads in the United States and Prussia

LARRY G. GERBER/The Irony of American Politics

Morton Keller and R. Shep Melnick, editors, Taking Stock:

American Government in the Twentieth Century

List of Articles from Volume 12 Issues 1 through 3 


\section{Journal of Policy History}

The Journal of Policy History provides an interdisciplinary forum for scholars concerned with the application of historical perspectives to public policy studies. The journal aims to encourage research into the formation and development of public policy while encouraging the application of diverse methods and theories to public policy and their politics within a historical perspective. In addition to social scientists and historians, the journal seeks to inform policy makers through a historical approach to public policy.

The Journal of Policy History is intended to give voice to scholars interested in understanding public policies and their development through historical inquiry and interpretation. The journal publishes historical studies of specific policy areas and policy institutions, and explores continuities and shifts in policy over time. The journal encourages interdisciplinary research into the origins and development of public policy in the United States and other countries. Comparative historical approaches to the development of public policies are also welcomed.

Manuscripts should be typed double-spaced with end notes following the text and generally should not exceed 30 typewritten pages. Manuscripts accepted for publication will be reviewed anonymously, and authors' names, including positions, addresses, and phone numbers, should appear only on the title page. Four copies of a manuscript, and a biographical sketch of no more than 50 words, should be sent to the Editor, Journal of Policy History, Saint Louis University, 3800 Lindell Blvd., P.O. Box 56907, St. Louis, MO 63156-0907.

The Journal of Policy History (ISSN 0898-0306) is published quarterly by The Pennsylvania State University Press, USB 1, Suite C, University Park, PA 16802. Annual subscription rates: U.S.A.: Individuals \$31./yr.; Institutions \$46./yr. Outside U.S.A.: Individuals, \$39./yr.; Institutions \$54.50/yr. All correspondence of a business nature, including subscriptions, permissions, advertisements, and changes of address, should be addressed to The Penn State Press. Subscribers are requested to notify the Press and their local postmaster immediately of change of address. POSTMASTER: Send address changes to The Penn State Press, USB 1, Suite C, University Park, PA 16802. E-mail Address: PSPjournals@psu.edu

This journal is registered with the Copyright Clearance Center, 222 Rosewood Drive, Danvers, MA 01923. Libraries and other users registered with the CCC may photocopy any article in the journal provided that a base fee of $\$ 1.00$ per copy is paid directly to the CCC. This authorization does not extend to copies made for duplicating an entire issue, for creating anthologies, for advertising, or for reselling. For information about multiple copying for classroom use, write to the Permissions Manager, The Penn State Press, at the address above.

The journal is submitted to the following for indexing: P.A.I.S. International, Humanities Abstracts, Institute for Scientific Information, University Microfilms Inc., Sage Publications, Sociological Abstracts, Historical Abstracts, and IBZ-International Bibliography of Periodical Literature.

Copyright (C) 2000 by The Pennsylvania State University. All rights reserved. No copies may be made without written permission of the publisher. 